\title{
Handbook of Women Biblical Interpreters: A Historical and Biographical Guide, edited by Marion A. Taylor with associate editor Agnes Choi
}

Grand Rapids: Baker Academic, 20I 2 | 608 pages | ISBN: 978o-80103-3568 (hardback) \$44.99| ISBN: 978-I-44I 23-8672 (ebook) $\$ 44.99$

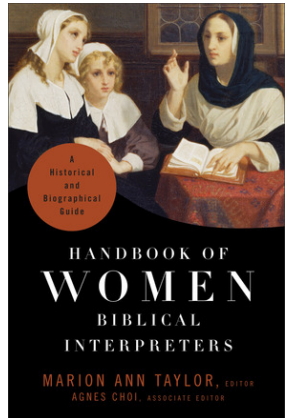

This is a truly fascinating volume. Handbooks are seldom enticing enough to be read from cover to cover; this one is an exception. It held my attention from the very first page and, as I turned the final page, I realized what a tour de force the book constitutes. Some of its articles astonished me: why did I not know of this woman and her accomplishments? Most of the articles humbled me: these women interpreters had been through so much hardship, faced so much opposition, and yet persevered. From Anne Askew who was imprisoned, tortured, and burned at the stake for her interpretations, to Margaret Dunlop Gibson and Agnes Smith Lewis who, despite their hard work and their brilliance, were never able to obtain permanent teaching posts.

It is always a daunting task to review a collection of articles. The present volume is no exception, containing I 80 relatively short entries. I have therefore chosen not to offer any detailed discussion of single entries. Rather I shall summarize my impression of the volume as a whole.

The Introduction lists the criteria upon which the selection of the entries was based. Taylor has sought to highlight women whose interpretations were (I) influential, (2) distinctive, or (3) representative of the type of interpretations offered by women of a certain historical period or geographical area. Taylor further emphasizes that even though many of the listed interpreters read the biblical texts through the lens of their experiences as women, such a focus did not constitute a criterion for inclusion in the Handbook. 
Several of the featured women interpreted the Bible "like a man" and a few even consciously objected to feminist readings. Finally, an interpreter had to be deceased in order to be given an entry. This last criterion meant that a number of influential twentieth-century women interpreters had to be left out.

The Introduction further offers a good general discussion of the shared and diverse backgrounds and achievement of the selected women interpreters. Taylor comments on their varied backgrounds, the different ways in which they obtained their learning and had access to academic and theological resources, their diverse motivations for studying the Bible, and also the large range of intended audiences for which they wrote. The Introduction also explores the ways in which the interpreters justified their work as Bible interpreters. Taylor notes that in many cases, the women drew on their own personal religious beliefs or the expressed theology of their religious affiliation to authorize their teaching. Often their belief of having been divinely inspired and called to their task lent affirmation to their writings.

Taylor also highlights that many women Bible interpreters centred their expositions and interpretations on certain key texts. First, she observes that Genesis (especially Gen I-3), Song of Songs, the Psalter, the Gospels, the Epistles (I Cor I I:3; Eph 5:2 I-33; Col 3:I 8-I 9; I Tim 2:I I-I 5; 5:I 4; I Pet $3: 1-7$; especially the texts which speak about women's role in the family and in the congregation), and Revelation are (unduly) well represented in their writings. Few women wrote systematic commentaries to any given book. Rather they refer to key passages in order to bolster a particular argument or theological point. Secondly, Taylor notices a strong interest in the female biblical characters and their fates. Women interpreters referred to narratives about Dinah and Tamar in order to condemn sexual violence against women, and they appealed to the leadership of Miriam, Deborah, Huldah, and Esther in order to show that God did not find it displeasing that women act as political and religious leaders.

Taylor also draws attention to the social consciousness which appears to have been a driving force behind many women interpreters and which shines through their written works. They interpreted the Bible so as to make a point in the contemporaneous political debate, be that the abolishment of slavery, social equality, education reform, or women's suffrage. Their interest in the Bible was seldom motivated by the pursuit of academic knowledge; instead it was often generated by their desire and also their expectation that the Bible would speak to their immediate situations. 
After reading the individual entries, I concur with Taylor's evaluation of the selected material and her summary of the findings.

The Handbook lists the interpreters in alphabetical order. The individual entries range from 2-5 pages, depending on and also reflecting their importance and impact, as well as our knowledge of and access to their writings. The entries are penned by a large number of contributors. Any one contributor has often written no more than one entry.

All the entries begin with a brief background description in order to place the interpreter in her social and religious location. This decision is symptomatic of the Handbook at large, because one of the key impressions that a reader gets from reading the Handbook is how much a person's personal and social circumstances influenced her decision and her ability to interpret the Bible. After that follows an overview of the interpreter's writing and a discussion of recurrent or dominant themes therein. In this overview, the contributor further highlights where and to what extent the interpreter focused on matters relating to women, either in the Bible or in her contemporaneous society. For instance, is her interpretation centred on passages in the Bible which deal with regulations regarding women, does it focus on biblical female characters, and/or does it deal with passages which are commonly used in political and religious discourse aimed at determining (and often curtailing) a woman's rights and responsibilities in society and in organized forms of religion? Most entries end with comments on the interpreter's legacy and the ways in which her interpretations have influenced later interpreters. Each entry also contains a select bibliography listing the interpreter's writing (often in English translation if the original is in another language) and key secondary literature.

After having read the Handbook in its entirety, it is near impossible to draw out any observations that relate to all the different interpreters. As discussed in the Introduction, the chosen women interpreters came from all social locations of society, they were single/married/widowed, some were childless while others had multiple children, etc. Yet, a few shared traits shine through the otherwise astonishing diversity. First and rather obviously, a Bible interpreter needs to be literate. This inevitably means that the majority of the listed interpreters came from the middle and upper classes. Secondly, fatherly support plays a key role in the development of a Bible interpreter. Women with an educated and supporting father are well represented among women interpreters. A budding Bible interpreter needs to have access to books and learning, as well as sufficient time to devote to them. Thirdly, 
personal suffering has an impact upon a person's decision to interpret the Bible. Many women sought and found comfort in the Bible because of personal misfortune and tragedy. A disproportionately high number of the listed Bible interpreters experienced the death of close family members (parents, husbands, children), and many suffered from ill health. Fourthly, the ability and interest in language study was a contributing factor to an interpreter's success. Quite a few women realized the importance of reading the Bible in the original languages. They offered new translations, based on the Hebrew or Greek text, of key passages as a way of combating gender-bias in the then existing translations.

My one point of concern with the Handbook is linked with its professed scope. Taylor states in the Introduction that she "attempted to be inclusive in terms of religious, cultural, racial, and geographical diversity" (6), yet she also notes that women from Western Europe dominate in the centuries leading up to and including the Reformation. After that, British and North American women stand in the foreground.

While I agree with the first part of this statement, I am less convinced by the second part. This Handbook is very much an English-language endeavour. Although key continental European women interpreters are represented, they are primarily from the Mediaeval Ages. Reading the Handbook can thus give the (incorrect) impression that from the Reformation and onwards, continental European women ceased to interpret the Bible. This English-language focus is felt in more than one area. First, a quick glance through the list of contributors reveals that most of them, with a few notable exceptions, received their $\mathrm{PhD}$ from and/or teach at institutes of higher education in North America and in the United Kingdom. Secondly, a high number of the entries deal with interpreters writing in English. These two observations go hand-in-hand. I suspect that had the editors sought out contributors working at continental European universities, there would also have been more entries devoted to non-English-speaking women interpreters.

Speaking as a Swede, it would for instance have been interesting to have an entry on Queen Kristina of Sweden (I626-I 689), alongside that of Queen Elizabeth I of England. The former wrote both an auto-biography and multiple letters, expounding on her understanding of God and the societal roles of women of power. It should be said, however, that Queen Kristina's religious writings seldom refer to specific Bible verses, an aspect which might disqualify her as a Bible interpreter. A Swedish woman that definitely would qualify as a woman Bible interpreter, however, is Lina Sandell Berg (1832-1903), the 
daughter of a Lutheran minister, who wrote more than 600 hymns. Notably, she used gendered female language to describe God's care for humanity (e.g., the original text of the song "Blott en dag"). Yet a third Swede that might have had a given place in a more internationally oriented handbook is the author Sara Lidman (1923-2004) whose five-volume book series Jernbaneeposet offers an innovative reading of the Sara-Hagar-Abraham narrative in Genesis. I am certain that a contemporary Dutch biblical scholar, or a Polish or a Greek one, would be able to come up with three equally influential women Bible interpreters from their countries, who lived during the last 300 years, were they asked to do so.

Lena-Sofia Tiemeyer

University of Aberdeen 